\title{
From the Persuasion of Theory to the Certainty of Law
}

\section{A Multi-Jurisdictional Analysis of the Law of Community Policing in Europe}

\section{Saleh Al-Sharieh}

Security, Technology and e-Privacy Research Group (STeP), University of Groningen

s.al-sharieh@step-rug.nl

Jeanne Mifsud Bonnici

Security, Technology and e-Privacy Research Group (STeP), University of Groningen

g.p.mifsud.bonnici@step-rug.nl

\begin{abstract}
This paper analyses the legal bases of community policing under European Union (EU) law and the national laws of England, France, Germany, Italy, Romania and Portugal. Community policing arguably helps the police achieve efficient policing while respecting the requirements of the rule of law, a founding value of the $\mathrm{EU}$, and can be a form of co-operation between the EU Member States under the EU legal framework for crime prevention. Moreover, the law in the selected jurisdictions supports four elements of the community policing model: (1) the public-police partnership in establishing policing strategies and priorities; (2) the public-police partnership for crime prevention and detection; (3) proactive and preventive policing; and (4) the police as providers of high quality services tailored to improve people's quality of life. These elements are interrelated and interdependent: their holistic legal articulation is necessary for their effective existence.
\end{abstract}

\section{Keywords}

multi-jurisdictional analysis - community policing - legality - rule of law - criminal justice - rights and freedoms 
The functions of the police in Europe are 'to maintain public tranquillity and law and order in society; to protect and respect the individual's fundamental rights and freedoms; to prevent and combat crime; to detect crime; [and] to provide assistance and service functions to the public.' ${ }^{1}$ The public contribute to these functions by, for example, reporting a criminal activity, submitting a piece of evidence, and practising citizen's arrests. ${ }^{2}$ The public-police partnership in preventing and detecting crimes is central to 'community policing,'3 which is a smart and effective management and operational philosophy of policing. ${ }^{4}$ Communities often understand their safety and security concerns more than professionals and thus can be innovative in suggesting solutions. ${ }^{5}$ Community policing strategies, initiatives and practices also emphasise that policing is a service, is driven by consent and is preventive. ${ }^{6}$

1 Council of Europe: Committee of Ministers. 2001. 'Recommendation Rec (2001)10 of the Committee of Ministers to Member States on the European Code of Police Ethics.' Council of Europe. September 2001. Retrieved 6 March 2017 www.refworld.org/docid/43f5c7944 .html. See also A.C. Germann, F.D. Day and R.R.J. Gallati, Introduction to Law Enforcement (Springfield: Charles C Thomas, 1962) 25 (arguing that the police maintain the peace in the community (community security) and protect life, property, and personal liberty (individual security)).

2 T.R. Tyler, Why People Obey the Law (Princeton: Princeton University Press, 2006) 87; T.R. Tyler, 'Enhancing police legitimacy', Annals of the American Academy of Political and Social Science 593(1) (2004) 84-99; W.G. Skogan, 'Citizen reporting of crime: Some national panel data', Criminology 13(4) (1976) 535-549.

3 J. Smith, 'Community policing as femme fatale', Southern Cross University Law Review 1 (1997) 75-91; K.J. Peak, 'Collaboration with outside agencies', in: K.J. Peak (ed.), Encyclopedia of Community Policing and Problem Solving (London: SAGE, 2013) 26-28.

4 L.P. Brown, 'Community policing: A practical guide for police officials', Perspectives on Policing 12 (1989) 1-11.

5 Peak (n 3); S. Ballantyne and P. Frase, 'It's good to talk, but it's not good enough: Active consultation as a key to safer communities', in: S. Ballantyne, K. Pease and V. McLaren (eds), Secure Foundations: Key Issues in Crime Prevention, Crime Reduction and community safety (London: London Institute for Public Policy Research, 2000). 164-188.

6 P.K. Manning, 'Community policing', American Journal of Police 3(2) (1984) 205-227; H. Groenewald and G. Peake, Police Reform through Community-Based Policing (New York: International Peace Academy, 2004) 2; V.E. Kappeler and L.K. Gaines, Community Policing: A Contemporary Perspective (New York: Routledge, 2015) 378; W.D. Granados, 'Nightsticks to Knighthood: A case for Articulation of Policing's Divergent Themes', Policing: An International Journal of Police Strategies \& Management 20(2) (1997) 374-391. 
Arguably, community policing reduces the trust gap between the public and the police to an extent that encourages respect for the law in society. ${ }^{7}$ Yet, this model of policing has received criticism on grounds such as: it fails to prevent abuses of the police powers ${ }^{8}$; it favours those interested in more policing over those who want more limitations to be placed on policing9; it assumes that communities are made of homogeneous actors that share the same idea on the importance of policing ${ }^{10}$; it is a form of 'romantic delusion' since the proximity it implies between the community and the police is not realistic ${ }^{11}$; it may endanger public safety ${ }^{12}$; and its actions face legality and legitimacy challenges. ${ }^{13}$

This paper discusses the legal grounds of community policing under European Union (EU) law and compares its legal bases both in jurisdictions where the police traditionally enjoy a high level of public trust (e.g. England and Germany) ${ }^{14}$ and in jurisdictions where trust in the police is relatively low

A. Goldsmith, 'Police reform and the problem of trust', Theoretical Criminology 9(4) (2005) 443-470; J. Hawdon, 'Legitimacy, trust, social capital, and policing styles', Police Quarterly $11(2)(2008) 182-201$.

J.E. Eck, 'Alternative futures for policing', in: D. Weisburd and C. Uchida (eds), Police Innovation and Control of the Police: Problems of Law, Order, and Community (New York: Springer-Verlag, 1993) 59-79.

M.I. Coombs, 'The constricted meaning of "community" in community policing', St.John's Law Review 72(3) (1998) 1367-1375.

L.M. Riechers and R.R. Roberg, 'Community policing: A critical review of underlying assumptions', Journal of Police Science and Administration 17(2) (1990) 105-114.

11 P.A.J. Paddington, 'Community policing: A sceptical appraisal', in: P. Norton (ed), Law and Order and British Politics (Aldershot: Gower Publishing Company, 1984) 84-99.

12 D.H. Bayley, 'Community policing: A report from the devil's advocate', in: J.R. Greene and S.D. Mastrofski (eds), Community Policing: Rhetoric or Reality (New York: Praeger, 1988) 225-237.

13 S.D. Mastrofski, 'Community policing as reform: A cautionary tale', in: J.R. Greene and S.D. Mastrofski (eds), Community Policing: Rhetoric or Reality (New York: Praeger Publishers, 1988) 47-67; K.J. Peak, B.G Stitt and R.W. Glensor, 'Ethical considerations in community policing and problem solving', Police Executive Research Forum 1(3) (1999) 19-34; J. Hughes, 'Theory of professional standards and ethical policing', in: A.M Vean, P. Spindler and C. Solf (eds), Handbook of Policing, Ethics, and Professional Standards (London: Routledge, 2013) 7-16.

14 B. Lobnikar, A. Sotlar and M. Modic, 'Do we trust them? public opinion on police work in plural policing environments in central and eastern Europe'. in: G. Mesko and J. Tankebe (eds), Trust and Legitimacy in Criminal Justice: European Perspectives (New York: Springer, 2015) 189-202; N. Guzy and H. Hirtenlehner, 'Trust in the German police: Determinants and consequences for reporting behavior', in: G. Mesko and J. Tankebe (eds), Trust and Legitimacy in Criminal Justice: European Perspectives (New York: Springer, 2015) 203-229; 
(e.g. France, Italy, Portugal and Romania). ${ }^{15}$ This is to increase the certainty as to the legality of community policing and to provide a better understanding of its different legality sources. ${ }^{16}$ The comparison further aims to show that community policing has legal bases even in jurisdictions where the public trust in the police is low and that the maturity level of the jurisdiction's community policing legal framework is an important, though not determinative, factor in building the public trust in the police.

Section 2 discusses the legal bases of community policing under EU law. Section 3 discusses and compares the legal bases of community policing in England, France, Germany, Italy, Portugal and Romania ('selected jurisdictions'), and Section 4 is a conclusion.

Community policing has two legal bases in Eu law: the rule of law and the crime prevention framework.

a

\section{The Rule of Law}

The rule of law is:

a principle of governance in which all persons, institutions and entities, public and private, including the State itself, are accountable to laws that are publicly promulgated, equally enforced and independently adjudicated and which are consistent with international human rights and standards. ${ }^{17}$

B. Flander and A. Bučar Ručman, 'Lost in transition: Criminal justice reforms and the crises of legitimacy in central and eastern Europe', in: G. Mesko and J. Tankebe (eds), Trust and Legitimacy in Criminal Justice: European Perspectives (New York: Springer, 2015) 111-133;J.T. Kääriäinen, 'Trust in the police in 16 European countries: A multilevel analysis', European Journal of Criminology 4(4) (2007) 409-435.

15 Kääriäinen (n 14); S. Staubli, Trusting the Police: Comparisons Across Eastern and Western Europe (Bielefeld: Transcript-Verlag, 2017) 65, 152; Lobnikar, Sotlar, and Modic (n 14).

16 See K. Zweigert and H. Kötz, An Introduction to Comparative Law, translated by T. Weir ( $3^{\text {rd }}$ edn, Oxford: Oxford University Press, 1998) 15-31 (discussing the functions and objectives of comparative law).

17 United Nations (UN) Security Council, The Rule of Law and Transitional Justice in Conflict and Post-Conflict Societies: Report of the Secretary-General, un Doc. S/2004/616, (23 August 2004), para. 6. 
It is one of the founding values of the $\mathrm{EU}$, along with the respect for human dignity, freedom, democracy, equality and human rights in general. ${ }^{18}$ The European Court of Justice (ECJ) has identified several elements of the rule of law including the principles of legality, legal certainty, proportionality and respect for several procedural guarantees, such as the right to be heard. ${ }^{19}$

The police ought to uphold the rule of law by enforcing democratically enacted laws to maintain order in society while respecting human rights and avoiding arbitrary actions. ${ }^{20}$ The police guard and are guided by the rule of law, ${ }^{21}$ but they are prone to violate it when focusing on efficiency in carrying out their duties to the detriment of human rights. ${ }^{22}$ As Jerome Skolnick explains, the 'tension between the operational consequences of ideas or order, efficiency, and initiative, on the one hand, and legality, on the other, constitutes the principal problem of police as a democratic legal organization. ${ }^{23}$

18 Consolidated Version of the Treaty on European Union, 2010 O.J. C 83/01 [TEU], preamble and Art. 2; Charter of Fundamental Rights of the European Union, preamble, 2010 O.J. C 83/02; C-550/og E and F [2010] ECR I-6213; C-583/11 P Inuit Tapiriit Kanatami and Others $v$ Parliament and Council [2013] EU:C:2013:625. See also T. Konstadinides, The Rule of Law in the European Union: The Internal Dimension (Oxford: Hart Publishing, 2017) (discussing the internal dimensions of the rule of law in the $\mathrm{EU})$.

19 T. Danwitz, 'The rule of law in the recent jurisprudence of the EcJ', Fordham International Law Journal 37(5) (2014) 1311-1347. See also European Commission for Democracy through Law (Venice Commission). Report on the Rule of Law - Adopted by the Venice Commission at the 86th Plenary Session. Venice, 25-26 March 2011. CDL-AD(2011)oozrev-e (listing as elements of the rule of law: '(1) Legality, including a transparent, accountable and democratic process for enacting law; (2) Legal certainty;(3) Prohibition of arbitrariness; (4) Access to justice before independent and impartial courts, including judicial review of administrative acts; (5) Respect for human rights (6) Non-discrimination and equality before the law').

20 The Organization for Security and Co-operation in Europe (OSCE): The Senior Police Adviser to the osce Secretary General, Guidebook on Democratic Policing $\left(2^{\text {nd }}\right.$ edn, Vienna: OSCE, 2008) para. 10.

21 S.A. Cohen, 'Invasion of privacy: Police and electronic surveillance in Canada', McGill Law Journal 27(4) (1982) 619-675.

22 See also J. Prinsloo and B. Kingshott, 'Ethics in policing', Phronimon 5(1) (2004) 49-70 (arguing that the police culture emphasises efficiency); C. Banks, Criminal Justice Ethics: Theory and Practice ( $2^{\text {nd }}$ edn, Los Angeles: SAGE, 2009) 23 (arguing that the abuse of the police powers is linked to police nature and culture).

23 J.H. Skolnick, Justice without Trial: Law Enforcement in a Democratic Society (New York: John Wiley \& Sons, 1966) 6. See also J. Reiman, 'Is police discretion justified in a free society', in: J. Kleinig (ed), Handled with Discretion: Ethical Issues in Police Decision Making (Lanham: Rowman \& Littlefield Publishers Inc., 1996) 71-83 (arguing that police discretion violates the separation of powers doctrine and threatens political liberty). 
Community policing aims to alleviate this tension. The public-police partnership may improve crime prevention and detection more than the work of the police alone.$^{24}$ It changes the public's perception of the role of the police from that of a force into a service provider, which encourages the public to communicate information that may facilitate crime prevention and detection. ${ }^{25}$ In this partnership, the public is actively involved in guarding the rule of law with the police. Indeed, to be effective, the rule of law must not only govern the state and its institutions but also be 'part of the moral tradition of the community.'26

Moreover, community policing is more akin to the 'due process' model of criminal justice, under which controlling crimes must not be at the expense of human rights, than to the 'crime control' model, which emphasises keeping criminals off the streets. ${ }^{27}$ Community policing focuses on protection, not control, and builds its programs on values such as accountability, transparency and respect for human rights. ${ }^{28}$ This approach changes the attitude of the public toward the police, and vice versa, to an extent that may encourage voluntary adherence to law. ${ }^{29}$ In this context, it is worth noting that 'criminal law's power to influence conduct may reside in large part in its normative rather than its coercive crime control mechanisms. ${ }^{30}$

24 D.H. Bayley, 'Law enforcement and the rule of law: Is there a tradeoff', Criminology \& Public Policy 2(1) (2002) 133-154; A.A. Aronowitz, 'Progress in community policing', European Journal on Criminal Policy and Research 5(4) (1997) 67-84. But see C. Gill et al., 'Community-oriented policing to reduce crime, disorder and fear and increase satisfaction and legitimacy among citizens: a systematic review', Journal of Experimental Criminology 10(4) (2014) 399-428 (concluding that the impact of community policing programs on crime is limited).

25 See V.J. Webb and C.M. Katz, 'Citizen ratings of the importance of community policing activities', Policing 2o(1) (1997) 7-23.

26 F.A. Hayek, The Constitution of Liberty (Chicago: University of Chicago Press, 1960) 205.

27 See H.L. Packer, 'Two models of the criminal process', University of Pennsylvania Law Review 113(1) (1964) 1-68 (discussing the due process and crime control models).

28 D. Prasad, 'Strengthening democratic policing and accountability in the commonwealth pacific', Sur - International Journal on Human Rights 5 (2006) 109-131.

29 See J.E. Eck and D.P. Rosenbaum, 'The new police order: effectiveness, equity, and efficiency in community policing', in: D.P. Rosenbaum (ed), The Challenge of Community Policing: Testing the Promises (London: SAge Publications, 1994) 3-23. A. Goldsmith, 'Police reform and the problem of trust', Theoretical Criminology 9(4) (2005) 443-470; J. Hawdon, 'Legitimacy, trust, social capital, and policing styles', Police Quarterly 11(2) (2008) 182-201.

$30 \quad$ P.H. Robinson, 'Why does the criminal law care what the layperson thinks is just? Coercive versus normative crime control', Virginia Law Review 86(6) (2000) 1839-1869. 
Scholars have expressed the concern that community policing may undermine the rule of law because of the problem-solving approaches it uses beyond the legal mandate of the police. ${ }^{31}$ The response to this is that the label 'community policing' does not by itself grant legality to policing activities that do not have grounds in law or are not respectful of the rule of law elements. Policing in collaboration with the public remains subject to the rule of law: the police remain accountable, and persons suffering a violation of their rights are entitled to the remedies prescribed by law. ${ }^{32}$

\section{b The EU Crime Prevention Framework}

The EU legal framework for crime prevention is one of the legal bases of community policing. First of all, the European Parliament and the Council can 'establish measures to promote and support the action of Member States in the field of crime prevention, excluding any harmonisation of the laws and regulations of the Member States. ${ }^{33}$ Therefore, they can prescribe measures that strengthen co-operation between the Member States. ${ }^{34}$ Community policing might be a domain of co-operation, since it is one of the zones of convergence between the EU Member States' policies in the area of crime prevention. ${ }^{35}$ In a communication to the Council and European Parliament, the Commission recommended that crime prevention policies be tailored at a local level, that the preventive measures involve a wide variety of actors and that local crime prevention polices be supported by co-operation measures at the EU level. ${ }^{36}$

31 See e.g. M. Brogden and P. Nijhar, Community Policing: National and International Models and Approaches (Devon: Willan Publishing, 2005) 59; M.H. Moore, 'Problem-solving and community policing', in: M. Tonry and N. Morris (eds), Modern Policing (Chicago: University of Chicago Press, 1991) 123-124; D.H. Bayley, Police for the Future (New York: Oxford University Press, 1994) 154 .

32 J.H. Skolnick, 'Democratic policing confronts terror and protest', Syracuse Journal of International Law and Commerce 33(1) (2005-2006) 191-212; Smith (n 3).

33 European Union. 2012. 'Consolidated version of the Treaty on the Functioning of the European Union'. European Union. 26 October 2012. Retrieved 6 March 2017 www.refworld.org/ docid/52303e8d4.html [TFEU], Art. 84 .

34 C. Harding, 'EU criminal law under the area of freedom, security, and justice', in: A. Arnull and D. Chalmers, (eds), The Oxford Handbook of European Union Law (Oxford: Oxford University Press, 2015) 837-866.

35 M. den Boer, 'Police, policy and politics in Brussels: Scenarios for the shift from sovereignty to solidarity', in: C. Kaunert, J. Occhipinti and S. Leonard (eds), Supranational Governance of Europe's Area of Freedom, Security and Justice (London: Routledge, 2015) $10-28$.

36 European Commission. 2004. 'Communication from the Commission to the Council and the European Parliament - Crime prevention in the European Union'. European 
Second, the European Parliament and the Council can adopt directives that define crimes and sanctions in cross-border serious crimes. ${ }^{37}$ These directives may establish crime prevention measures that are community policing oriented. For instance, the $\mathrm{EU}$ directive on preventing and combating trafficking in human beings and protecting its victims ${ }^{38}$ requires Member States to take, where appropriate, suitable measures 'in cooperation with relevant civil society organisations and other stakeholders, aimed at raising awareness and reducing the risk of people, especially children, becoming victims of trafficking in human beings. ${ }^{39}$ Community policing is an important approach to combat human trafficking and protect its victims. ${ }^{40}$

Third, the European Council is in charge of designing the strategic guidelines for legislative and operational planning within the area of freedom, security and justice. ${ }^{41}$ For instance, it adopted the Stockholm Programme (2010-2014) - an open and secure Europe serving and protecting citizens which emphasised effective crime prevention through the co-operation between authorities and citizens for the purpose of developing an area of

Union. 16 April 2004. Retrieved 6 March 2007 www.eur-lex.europa.eu/legal-content/EN/ TXT/?uri=URISERV\% ${ }_{3} \mathrm{Al}_{3325}$. Several EU policies and measures have emphasized the role of community policing in crime prevention. See also Council of the European Union. 1998. 'Council Resolution of 21 December 1998 on the prevention of organised crime with reference to the establishment of a comprehensive strategy for combating it'. European Union. 29 December 1998. Retrieved 6 March 2017 www.eur-lex.europa.eu/legal-content/ EN/TXT/?uri=URISERV\%33133149: (stating that the " $\mathrm{r}$ ] esponsibility for the prevention of crime lies not only with the judicial authorities and the police but also with civil society as a whole').

TFEU (n 33) Art. 83(1). See also TfEU (n 33) Art. 82(1). For a discussion of the EU competence in criminal law, see J.I. Turner, 'The expressive dimension of Eu criminal law', The American Journal Of Comparative Law 60 (2010) 555-584; E. Herlin-Karnell, 'EU competence in criminal law after Lisbon', in: A. Biondi, P. Eeckhout and S. Ripley (eds), EU Law After Lisbon (Oxford: Oxford University Press, 2012) 331-346; R. Sicurella, 'EU Competence in Criminal Matters', in: V. Mitsilegas, M. Bergström and T. Konstadinides (eds), Research Handbook on EU Criminal Law (Cheltenham: Edward Elgar, 2016) 49-77.

38 European Union. 2011. 'Directive 2011/36/EE of the European Parliament and of the Council of 5 April 201 on preventing and combating trafficking in human beings and protecting its victims, and replacing Council Framework Decision 2002/629/JHA'. European Union. 15 April 2011. Retrieved 6 March 2017 www.eur-lex.europa.eu/LexUriServ/LexUriServ.do? uri=OJ:L:2011:101:0001:0011:EN:PDF.

39 Ibid., Art.18(2).

40 The Organization for Security and Co-operation in Europe (OSCE), Trafficking in Human Beings: Identification of Potential and Presumed Victims (Vienna: OSCE, 2011) 34-43. tfeu (n 33) Art. 68. 
freedom, security and justice. ${ }^{42}$ Further, the European Council re-established the European Crime Prevention Network (EUCPN) to develop and co-ordinate crime prevention aspects at the EU level and support crime prevention measures taken at the national and local levels. ${ }^{43}$ Some of the EUCPN's duties focus on the promotion of preventive policing and on encouraging the public-police partnership in crime prevention and detection. Particularly, it has a duty to 'facilitate cooperation, contacts and exchanges of information and experience between actors in the field of crime prevention'44 and 'be in close contact, through the national representatives and the contact points, with crime prevention bodies, local authorities, local partnerships and civil society as well as with research institutions and nongovernmental organisations [NGOs] in the Member States. 45

\section{The National Legal Frameworks of Community Policing}

England recognised the idea of community policing early on, in the Metropolitan Police Act, ${ }^{46}$ which established a modern, centralised and unified police force in London. ${ }^{47}$ Echoing Sir Robert Peel's Nine Principles of Law Enforcement, ${ }^{48}$ the Metropolitan Police Act emphasised preventive policing

42 European Union. 2010. 'The Stockholm Programme - An open and secure Europe serving and protecting citizens'. European Union. 4 May 2010. Retrieved 6 March 2017 www.eur -lex.europa.eu/legal-content/EN/TXT/?uri=celex:52010XGo504(01).

43 Council of the European Union. 2009. 'Council Decision 2009/902/JHA of 30 November 2009 setting up a European Crime Prevention Network (EUCPN) and repealing Decision 2001/427/JHA'. European Union. 8 December 2009. Retrieved 6 March 2017 www.eur-lex .europa.eu/LexUriServ/LexUriServ.do?uri=OJ:L:2009:321:0044:0046:EN:PDF.

44 Ibid., Art. 4(a).

45 Ibid., Art. 5(b). Recently, there have been calls for creating a technical group focusing on community policing within the European Council in the policy area of freedom, security and justice. See e.g. Council of the European Union. 2015. 'European Police Chiefs Convention 2015: Summary and Recommendations'. European Union. 20 October 2015. Retrieved 6 March 2017 www.statewatch.org/news/2015/nov/eu-council-eppc-2015-report-o9-2015 .pdf.

$46 \quad 10$ Geo 4 c.44 (Metropolitan Police Act) (1829).

47 J.L. Lyman, 'The Metropolitan Police Act of 1829',Journal of Criminal Law and Criminology 55(1) (1964) 141-154.

48 R. Peel. 1929. 'Sir Robert Peel's Principles of Law Enforcement 1829'. Retrieved 6 March 2017 www.durham.police.uk/About-Us/Documents/Peels_Principles_Of_Law_Enforcement .pdf [Peel's Nine Principles]. 
and the public-police partnership. ${ }^{49}$ Since then, the legal framework of community policing has significantly evolved in England and later developed in the other selected jurisdictions. In each jurisdiction, the law explicitly or implicitly supports at least three aspects of community policing: the public-police partnership, preventive policing and policing as a service.

a

Public-Police Partnership in Setting Policing Strategies and Priorities

The English legal system is a pioneer in supporting co-operation between the public and police in establishing policing priorities and strategies. In England, a local policing body has a duty to take the necessary measures for collecting views from the victims of crimes and the community members about policing..$^{50}$ The local policing body has another duty to collect the views of both groups on the 'police and crime plan' before it is issued by the Police and Crime Commissioner for a policing area or by the Mayor's Office for Policing and Crime for the Metropolitan Police District. ${ }^{51}$ This happens through online and offline surveys, workshops or focus groups. ${ }^{52}$ The police and crime plan sets out the police objectives for the financial year and the resources designated to achieve them in accordance with the national policing plan. ${ }^{53}$

Furthermore, the Crime and Disorder Act $1998^{54}$ establishes Community Safety Partnerships (CSPs) to formulate and execute crime control strategies. ${ }^{55}$ csps include the local police, the local council, probation services, local health service bodies and emergency authorities. ${ }^{56}$ In each local government area, there is a strategy group in charge of preparing strategic assessments in addition to preparing and implementing a partnership plan on behalf of the

49 See J.S. Dempsey and L.S. Forst, An Introduction to Policing, 5th ed (Clifton Park, NY: Delmar, 2010) 8; Lyman (n 48).

5o Police Act 1996, c.16, s.96 (1) (a)-(b).

$51 \quad$ Ibid., s.96 (1A).

52 C. Harfield, Blackstone's Police Operational Handbook: Practice and Procedure (Oxford: Oxford Press, 2009) 283.

53 Police Reform and Social Responsibility Act 2011, c.13, s.7. This Act replaced the Metropolitan Police Authority with the Mayor's Office for Policing and Crime and replaced the police authorities outside London with elected Police and Crime Commissioners. See H. Barnett, Constitutional and Administrative Law (10 ${ }^{\text {th }}$ edn, London: Routledge, 2013) 500-510.

54 Crime and Disorder Act 1998, c.37.

55 Ibid., s.6.

$56 \quad$ Ibid., s.5. 
partners of the csP. ${ }^{57}$ The partnership plan sets out the crime control strategy, the community safety priorities and the measures and resources necessary for implementation. ${ }^{58}$ The strategy group has a duty to engage the public in the preparation and implementation of the partnership plan. ${ }^{59}$ Thus, it must make arrangements to collect the views of community members about: '(a) the levels and patterns of crime and disorder and substance misuse in the area; and (b) the matters which [the partners of the CSP] should priorities when each are exercising their functions to reduce crime and disorder and to combat substance misuse in the area. ${ }^{60}$ The strategy group must seek views on those issues from persons representing the interests of as many different groups in the community as possible, especially groups that will likely be affected by the implementation of the partnership plan. ${ }^{61}$ Therefore, it must hold public meetings that join senior representatives of the authorities, members of the strategy group and community members. ${ }^{62}$

Moreover, in England, the strategy group has a duty to consult the public in the process of preparing the strategic assessments, which are used in revising the partnership plan. ${ }^{63} \mathrm{~A}$ county strategic group will also use the yearly strategic assessments to prepare community safety agreements that describe how the different partners in the county strategic group will collaborate to implement the community safety priorities set out in the strategic assessments and how those partners may otherwise effectively collaborate to reduce the rate of crime and disorder in the county. ${ }^{64}$

The Crime and Disorder Act 1998 decentralised the responsibility for policing in England. ${ }^{65}$ The police share the responsibility of fighting crime and disorder in the community with multiple local agencies. ${ }^{66}$ In this structure, the

\footnotetext{
57 The Crime and Disorder (Formulation and Implementation of Strategy) Regulations 2007, SI 1994/1830, s.3.

58 Ibid., s.10-11.

59 Ibid., s.12 (1)-(2).

6 Ibid., s.12 (1).

$61 \quad$ Ibid., s.12 (2).

$62 \quad$ Ibid., s.12 (4).

63 Ibid., s.5, 6 and 12 (1).

64 Ibid., s.9.

65 B. Loveday, 'Police accountability in the provinces: The changing role of the police authority', Crime Prevention and Community Safety: An International Journal 3(2) (2001) 49-63.

66 F. Leishman, B. Loveday and S.P. Savage, 'Introduction: Core issues in policing revisited', in: F. Leishman, B. Loveday and S.P. Savage (eds), Core Issues in Policing, and ed (Edinburgh: Pearson Education, 2000) 1-7.
} 
role of the local community in policing is as important as the role of any other local agency involved in the CSP. ${ }^{67}$

The legal systems in France and Romania are the closest to the English system with respect to the emphasis on the public-police partnership in setting policing strategies and priorities. Each French municipality has a local council for safety and crime prevention whose role is to identify security and crime prevention goals, strategies and actions in collaboration with the local public and private entities, including community representatives. ${ }^{68}$ The work of the local council influences policing within the municipality and could influence policing priorities and strategies in other municipalities through the work of the Inter-communal Council for Security and Crime Prevention, which co-ordinates the security and crime prevention actions amongst the municipalities. ${ }^{69}$

Romania has adopted another model by which the public's influence on policing strategies and priorities is implicit in the duty of the police to fulfil their mandate in collaboration with other state departments, non-governmental institutions and legal and natural persons..$^{70}$ The law establishes in Bucharest and in each county the Territorial Authority of Public Order, which includes members representing the police and the community, to provide consultations on how to tailor policing services to protect the community interest. ${ }^{71}$ Mayors also have a duty to organise periodic consultation meetings with local community members to discuss the priorities of the local police. ${ }^{72}$ Furthermore, the studies of the Institute for Crime Inquiry and Prevention on crime control resemble another form of public consultation as they receive inputs from the community and education institutions. ${ }^{73}$

67 See T. Newburn, 'Community Safety and Policing: Some Implications of the Crime and Disorder Act 1998', in: G. Hughes, E. McLaughlin and J. Muncie (eds), Crime Prevention and Community Safety: New Directions (London: SAGE Publications, 2002) 102-122 (arguing that the Crime and Disorder Act 'reinsert[s] the community into policing').

68 Loi n ${ }^{\circ}$ 02-1094 du 29 août 2002, Annex I, Art. I.

69 Ord. n ${ }^{\circ} 12-351$ du 12 mars 2012, Art. L132-13.

70 Law 218/2002 on the Organisation and Functioning of Romanian Police published in the Official Gazette no. 308/09.05.2002, Arts. 1 and 3.

71 Ibid., Art. 17.

72 Law No. 155/2010 on Local Police published in the Official Monitor no. 488/12.07. 2010, Art. $3^{1}(\mathrm{i})$. See also F. Mateaş, 'Duties of the local police regarding the security of objectives, goods, valuables and the protection of individuals', AGORA International Journal of Juridical Sciences 2 (2014) 40-49 (discussing local policing in Romania).

73 P. Abraham, 'Community policing in Romania: De factum, tendencies, solutions', in: OsCE. 2002. 'The Role of Community Policing in Building Confidence in Minority 
By contrast, there is no clear statutory duty to engage the public in establishing policing strategies and priorities in the other selected jurisdictions. The public may influence policing in Italy and Portugal to the extent that they may generally influence the government's decision-making through the democratic channels prescribed by the Constitution and other relevant laws. ${ }^{74}$

Unlike the other selected jurisdictions, Germany is a federal state: the federal parliament legislates on criminal law whereas the parliaments of the 16 states (Länder) legislate on state police matters. ${ }^{75}$ Therefore, the forms of the public-police partnership in setting policing priorities and strategies may differ from one state to another. In each state, the Ministry of Interior has the power to adopt the policies necessary for the achievement of its mandate and to sponsor initiatives to collect the views of the citizens on policing priorities and strategies. ${ }^{76}$ For instance, the Ministry of Interior in Baden-Württemberg has used questionnaires to collect the views of the citizens on local crimes, particularly their nature and patterns, location, community impact and control measures. ${ }^{77}$ This approach enables the local government to locate security problems in the community and prescribe community-tailored solutions. ${ }^{78}$ In addition, the Ministry of Interior can establish or encourage the creation of 'crime prevention councils', 'crime prevention bodies' and 'partnerships for public order' to facilitate public engagement in setting policing priorities and strategies. ${ }^{79}$ For instance, North Rhine-Westphalia has formed partnerships

Communities: Final Report'. OSCE. 18-19 October 2002. Retrieved 6 March 2017 www.osce .org/odihr/19923?download=true.

74 See Council of Europe, Structure and Operation of Local and Regional Democracy: Portugal (Strasbourg: Council of Europe Publishing, 1998) 18-20.

75 Arts. 71-73 and 74 Abs. 7 G G. Although under the Grundgesetz criminal law is a concurrent jurisdiction matter, the Länder can only legislate 'to the extent that the Federation [federal parliament] has not exercised its legislative power by enacting a law.' Art. 72(1) Abs.7 G G. It is worth noting that the federal parliament has exclusive legislative competence in matters relating to the cooperation between the states and the federation regarding 'criminal police work.' Ibid., Art. 73 Abs. 1 G G.

76 See e.g. Art. 5 Verfassung für das Land Nordrhein-Westfalen v. 28.o6.1950, GV. NRW. 28 1950, 127.

77 T. Feltes, 'Community policing in Germany', in: Institute for Peace Research and Security Policy at the University of Hamburg/Ifsh, (ed), osCE Yearbook 2013: Yearbook on the Organization for Security and Co-operation in Europe (Baden-Baden: Nomos Verlagsgesellschaft, 2014) 219-230.

78 Ibid.

79 Ibid.; M. Jasch, 'Going around in circles? Reflections on crime prevention strategies in Germany', in: A. Crawford (ed), Crime Prevention Policies in Comparative Perspective (New York: Routledge, 2009) 196-213. 
involving the police and other local stakeholders for public order in its towns and cities. ${ }^{80}$ Notably, in this state, the police statute explicitly requires the police to establish an advisory board to: (a) promote the trust between the community, the local government and the police; (b) support the work of the police; and (c) communicate the concerns and wishes of the community to the police. ${ }^{81}$

The citizens' participation in governmental decision-making in Germany through different democratic channels, such as citizens' applications and assemblies, further facilitates the public-police partnership in establishing policing priorities and strategies. ${ }^{82}$ For instance, in Bavaria citizens have a 'joint consultation right' that requires the mayor to call for a citizens' assembly at least once a year to discuss the municipality's affairs. ${ }^{83}$ These assemblies enable citizens to share their opinions and concerns regarding the municipality matters, ${ }^{84}$ including policing. ${ }^{85}$

\section{b Public-Police Partnership in Crime Prevention and Detection}

The emphasis on the public-police partnership in crime prevention and detection is conspicuous in the legal frameworks of policing in England and Romania. The English police have a duty to make arrangements that secure people's co-operation in crime prevention. ${ }^{86}$ In addition, the strategy group preparing the community safety partnership plan - discussed above - is required to consider the feasibility of engaging the public in crime control in their communities. ${ }^{87}$ Similarly, the Romanian police have a duty to co-operate with the local authorities and representatives of the community for the purpose of crime prevention and detection. ${ }^{88}$ For instance, the police have entered into a partnership with the Ovidiu Rom Association in order to implement crime

\footnotetext{
$80 \quad$ Feltes ( $\mathrm{n} 77)$.

81 Art. 16 Polizeiorganisationsgesetz (POG NRW) v. 5.07.2002, GV. NRW. 19 2002, 308.

82 For a discussion of all the forms of citizens' direct and indirect participation in decisionmaking in Germany, see Council of Europe, Structure and Operation of Local and Regional Democracy: Germany (Strasbourg: Council of Europe, 1998) 16-17.

83 Art. 18 Abs. 1 Gemeindeordnung für den Freistaat Bayern v. 22.08.1998, GVBl. 21 1998, 796 .

$84 \quad$ Ibid., Art. 18 s.3.

85 Art. 381 Verfassung des Freistaates Bayern v. 2.12.1946, GVBl. 23 1946, 333.

86 Police Act 1996 (n 5o) s.96 (1)(a).

87 The Crime and Disorder (Formulation and Implementation of Strategy) Regulations 2007 (n 57) s.13.

88 Law 218/2002 on the Organisation and Functioning of Romanian Police (n 7o) Art. 22(1).
} 
prevention projects to counter juvenile delinquency and child victimisation among the Roma population. ${ }^{89}$

Establishing a partnership with the public for the purpose of crime prevention and detection generally falls within the discretionary powers of the Ministry of Interior and/or the police organisations in the other selected jurisdictions. The Portuguese Public Security Police (PSP) have a broad mandate of ensuring the safety and security of the communities that fall within their jurisdiction and, while doing so, they must co-operate with other forces and public authorities, especially local government authorities..$^{90}$ The Integrated Programme of Proximity Policing, combining the different crime control projects and initiatives of the $\mathrm{PSP}^{91}$ has created a stronger link between the police and the communities they serve by increasing the presence of the police in the community, ${ }^{92}$ providing policing services tailored to the needs of the local communities and providing policing services in collaboration with the private and public local bodies. ${ }^{93}$ Under this programme, the PSP have created proximity policing teams responsible for preventing domestic violence, detecting potential crimes and providing support to crime victims. ${ }^{94}$ Proximity policing teams rely on trained proximity police officers for the purpose of improving the safety culture in the community. ${ }^{95}$ They perform different forms of patrol,

89 United States Department of State, Bureau of Democracy, Human Rights and Labor. 2011. 'Country Reports on Human Rights Practices for 2011: Romania'. United States Department of State. 2011. Retrieved 6 March 2017 www.state.gov/documents/organization/1866o6.pdf at 26 [Human Rights Practices for 2011: Romania].

9o Law No. 53/2007 Approving the Organizational Structure of the Public Security Police, $3^{1}$ August, Art. 6(1).

91 United Nations Committee on the Elimination of Racial Discrimination (CERD). 2011. 'Reports submitted by States Parties under Article 9 of the Convention'. United Nations Committee on the Elimination of Racial Discrimination. 13 September 2011. Retrieved 6 March 2017 www2.ohchr.org/english/bodies/cerd/docs/CERD.C.PRT.12-14_en.pdf para. 113; L.F. Fernandes, 'Community policing in Portugal: A long and winding road', in: M.C. de Guzman, A.M. Das and D.K. Das (eds), The Evolution of Policing: Worldwide Innovations and Insights (Boca Raton: CRC Press, 2014) 181-190.

92 Fernandes (n 91); CERD (n 91).

93 Fernandes (n 91).

94 United Nations Committee on the Elimination of Discrimination againstWomen(CEDAW). 2008. 'Consideration of reports submitted by States parties under article 18 of the Convention: Seventh Periodic Report of States Parties (Portugal)'. United Nations Committee on the Elimination of Discrimination against Women. 29 January 2008. Retrieved 6 March 2017 www2.ohchr.org/english/bodies/cedaw/docs/CEDAW.C.IND.4-5_en.pdf.

95 State Report. 2012 'Initial Report of Portugal on the implementation of the Convention on the Rights of Persons with Disabilities'. SR. August 2012. Retrieved 6 March 2017 www .ohchr.org/Documents/HRBodies/CRPD/Future/CRPD.C.PRT.1.doc; Fernandes (n 91). 
respond to minor safety problems in the community and detect potential local security problems. ${ }^{96}$ In the course of their activities, they co-operate with the community members, whether natural or legal persons, non-governmental organisations (NGOS) and local authorities. ${ }^{97}$

Similarly, the Italian Ministry of Interior has the power to develop community policing programmes, such as neighbourhood watch programmes, in order to engage the public in crime prevention, facilitate crime reporting and improve the relations between the police and the communities they serve. ${ }^{98}$ At the local level, the Mayors of the municipalities oversee policing, issue regulations for public order and security within their municipalities and promote collaboration between the local and national police. ${ }^{99}$ Because of this broad mandate, they have the power to propose security and safety initiatives that promote collaboration between the police and the community for the purpose of crime prevention. For instance, some municipalities have hired former police officers to patrol public parks and schools. ${ }^{100}$ This level of the public's involvement in crime prevention and detection also echoes the situation in France, where individuals can volunteer to assist in joint patrols with the police, become involved in social mediation and deliver crime prevention education. ${ }^{101}$ The volunteers do not exercise public power prerogatives. ${ }^{102}$

In Germany, the public-police partnership in crime prevention and detection originates from the same legal and institutional framework of the publicpolice partnership in setting up policing priorities and strategies at the state level ${ }^{103}$ : specifically, the crime prevention councils, crime prevention bodies and partnerships for public order. ${ }^{104}$ These bodies create 'an inter-agency

\footnotetext{
$96 \quad$ SR. 2012 (n 93); Fernandes (n 91); CEDAW (n 94).

97 Ibid.; Fernandes (n 91).

98 Legge 15 Juglio 2009, n. 94, in G.U 24 Luglio 2009, Art. 3, para. 40, replacing Art. 36 of Legge 5 Febbraio 1992, n. 104, para. 1; S. Caneppele, 'Italy', in: M.K. Nalla and G.R. Newman (eds.), Community Policing in Indigenous Communities (Boca Raton: CRC Press, 2013) 267-274. Legge 24 Luglio 2008, n. 126, in G.U. 25 Luglio 2008, n. 173, Art. 6, amending Decreto Legislativo 18 Augusto 2008, n. 267.

100 Caneppele (n 98).

101 Ord. $\mathrm{n}^{\circ} 12-351$ du 12 mars 2012, Art. L433-1.

102 Ibid.

103 See Jasch, (n 79).

104 See the discussion in s.3.1, above.
} 
approach to crime prevention' according to which the police and the justice agencies may collaborate with other public and private partners in preventing crimes. ${ }^{105}$ Moreover, the federal government collaborates with the governments of the states under the umbrella of the Crime Prevention Forum, which adopts the philosophy that crime prevention is also a society's duty and, accordingly, engages many public and private actors in its work. ${ }^{106}$

The public-police partnership in crime prevention and detection emerges not only from policing statutes but also from other laws, such as criminal law. For instance, the failure to report a crime is a criminal offence in Germany, Romania, France and Italy. ${ }^{107}$ The criminal law in Germany, France, Italy, Romania and Portugal establishes a duty to rescue. ${ }^{108}$ Additionally, the criminal procedures law in these jurisdictions, and in England, allows citizen's arrests: the legal authorisation of everyone to arrest a person caught in a criminal act or being pursued because of a criminal act, subject to specific conditions provided in the law. ${ }^{109}$

\section{$105 \operatorname{Jasch}(\mathrm{n} 79)$.}

106 S. Mohanty and R.K. Mohanty, Community Policing as a Public Policy: Challenges and Recommendations (Newcastle upon Tyne: Cambridge Scholars Publishing, 2014) 88.

107 Section 138 S.1-3 StGB; Art.266, C. Pen.; Art. 434-1 C. pén.; Arts. 331, 361, 362 cod. pen. Besides criminal law statutes, other statutes may impose an obligation to report crimes. See e.g. Art. 11 Gesetz zur Ergänzung der Bekämpfung der Geldwäsche und der Terrorismusfinanzierung (Geldwäschebekämpfungsergänzungsgesetz- GwBekErgG) v. 13.08.2008, BGBl. I 2008, 1690 (requiring financial institutions to report financial transactions involving property or assets reasonably suspected to be a product of a crime or related to terrorism financing). There is no general duty to report crimes in England, since the Criminal Law Act 1967 abolished the offence of 'misprision of felony.' C. Gosnell, 'Damned if You Don't: Liability for Omissions in International Criminal Law', in: W.A. Schabas, Y. McDermott and N. Hayes (eds), The Ashgate Research Companion to International Criminal Law: Critical Perspectives (Farnham: Ashgate, 2013) 101-132. Nonetheless, there are statutes, such as the Proceeds of Crime Act 2002, c.29, that impose a duty to report specific crimes. Similarly, the Penal Code of Portugal does not include a general duty to report crimes but criminalises one's failure to disclose information he/she has relating to money laundering activities. See Penal Code, Decree-Law No. 400/82, 23 September 1982, art. 368-A.

108 Section 323c StGB; Art. 223-6, 223-7 C. pén.; Art. 593 cod. pen; Art. 203, C. Pen.; Penal Code, Decree-Law No. 40o/82 (n 107) Art. 200(1). See also D. Schiff, 'Samaritans: Good, bad and ugly: A comparative law analysis', Roger Williams University Law Review 11(1) (2005) 77-141; D.M. Reckseen, 'The duty to rescue', Indiana Law Journal 47(2) (1972) 321-330.

109 Police and Criminal Evidence Act 1984, c.6o, s.24A (1)-(2); Art. 73 C. pr. pén; Art. 383 cod. proc. pen.; Código de Processo Penal, Decreto-Lei n. ${ }^{\circ} 78 / 87$, de 17 de Fevereiro Decreto-Lei n. ${ }^{\circ} 78 / 87$, de 17 de Fevereiro 1987, Art. 255(1)(b); Section 127 StPO. Art. 310, C. Proc. Pen. 


\section{c Preventive Policing}

Preventive policing refers to the approach in which 'the police, acting on their own initiative, develop information about crime and strategies for its suppression."110 It is the first principle in Sir Robert Peel's Principles of Law Enforcement: '[ $t$ ] he basic mission for which police exist is to prevent crime and disorder as an alternative to the repression of crime and disorder by military force and severity of legal punishment.'111 Crime prevention is one of the values and missions of the police in the selected jurisdictions, ${ }^{112}$ for it reduces victimisation and the cost of the criminal justice system. ${ }^{13}$

Preventing crimes requires understanding of their root causes and an evidence-based approach to addressing them. ${ }^{114}$ In this respect the Home Secretary issues crime prevention strategies identifying drivers of crimes and measures to counter them in England. ${ }^{115}$ Similarly, the federal Commission on Police-Based Crime Prevention in Germany and the Territorial Authority of Public Order established in Romania's capital and counties are important fora

110 J.P. Crank, Understanding Police Culture (New York: Routledge, 2004) 296.

111 Peel (n 48). See also V.E. Kappeler and L.K. Gaines, Community Policing: A Contemporary Perspective (New York: Routledge, 2015) 378 (arguing that preventive policing is an important element of the community policing paradigm).

112 See e.g. Art. 1 Abs. 5 Gesetz über den Bundesgrenzschutz v. 19.10.1994, BGBl. I (1994), 1834; Art. 1 Abs. 2-3 Polizeigesetz des Freistaates Sachsen v. 13.08.1999, SächsGVBl. (1991) 890; Law No. 53/2007 Approving the Organizational Structure of the Public Security Police (n 9o) Art. 3; Ord. n ${ }^{\circ} 12-351$ du 12 mars 2012, Arts. L132-1 to L132-15; Law 218/2002 on the Organisation and Functioning of Romanian Police ( $\mathrm{n}$ 70) Art. 1. Association of Chief Police Officers England, Wales and Northern Ireland, (ACPO), Statement of Mission and Values (ACPO). July 2011, quoted in S. Kirby, Effective Policing?: Implementation in Theory and Practice (Basingstoke, UK: Palgrave Macmillan, 2013) 28.

113 Her Majesty's Inspectorate of Constabulary (HMIC). 2014. 'Core business: An inspection into crime prevention, police attendance and the use of police time'. HMIC. September 2014. Retrieved 6 March 2017 www.justiceinspectorates.gov.uk/hmic/wp-content/uploads/core -business.pdf at 22 .

114 See B.C. Welsh and D.P. Farrington, 'Evidence-based crime prevention', in: B.C. Welsh and D.P. Farrington, (eds), Preventing Crime: What Works for Children, Offenders, Victims, and Places (Dordrecht, NL: Springer, 2006) 1-17. See also B.C. Welsh and D.P. Farrington, 'Crime prevention and public policy', in: D.P. Farrington and B.C. Welsh (eds), The Oxford Handbook of Crime Prevention (Oxford: Oxford University Press, 2012) 3-20 (reviewing common crime prevention methods).

115 See e.g. United Kingdom Home Office. 2016. 'Modern Crime Prevention Strategy'. Home Office. March 2016. Retrieved 6 March 2017 www.gov.uk/government/uploads/system/ uploads/attachment_data/file/509831/6.1770_Modern_Crime_Prevention_Strategy_final_ WEB_version.pdf. 
for crime prevention research. ${ }^{116}$ The recommendations and manuals of these bodies are designed to help police departments develop effective crime prevention programmes. In contrast, Portugal does not have a national-level body for crime prevention. ${ }^{117}$ However, in recent years, it has taken noticeable steps in building its crime prevention capacity. By its fifth National Plan against Domestic Violence (2014-2017), ${ }^{118}$ Portugal aims to provide a comprehensive strategy for crime prevention and victim protection. The plan has five strategic areas under each of which a number of measures are to be applied:'(1) Prevent, raise awareness and educate; (2) Protect victims and promote their integration; (3) Intervene with perpetrators; (4) Train and qualify professionals; (5) Investigate and monitor.'119

Preventing offending by children and young persons is an important part of preventive policing. ${ }^{120}$ For this reason, the English police have a duty to collaborate with the different actors in the youth justice system, such as the local probation and health authorities, to prevent offending by children and young persons. ${ }^{121}$ The establishment of local multi-disciplinary youth offending teams responsible for addressing youth offending locally is an important form of this collaboration. ${ }^{122}$ The prevention of the juvenile delinquency is particularly the focus of crime prevention in Portugal, ${ }^{123}$ where municipalities adopt

116 Mohanty and Mohanty (n 106) 87-89.

117 J. Kulach, N. Whiskin and E. Marks, Cultures of Prevention Urban Crime Prevention Policies in Europe: Towards A Common Culture (La Rochelle: Imprimerie Rochelaise, 2006) 30.

118 Resolution of the Council of Ministers 102/2013, Official Journal No. 253, 1st series, 31 December 2013 .

119 European Crime Prevention Network (EUCPN). 2014. 'Domestic Violence: Portugal'. European Crime Prevention Network. 2014. Retrieved 6 March 2017 www.eucpn.org/sites/ default/files/content/download/files/po_pt_dv_policy_supp_2014.pdf.

120 G.A. Res. 45/112, UNGAOR, 45th Sess., Supp. No. 49, vol. 1, p. 200, UN Doc. A/RES/45/112 (1990).

121 Crime and Disorder Act (n 54) s.37 and s.38. See also J. Fionda, 'New labour, old hat: Youth justice and the Crime and Disorder Act 1998', Criminal Law Review (1999) 36-47 (stating that the Act 'represents a melting pot of principles and ideologies that mix punishment and welfare approaches'); K. Evans, Crime Prevention: A Critical Introduction (Los Angeles: SAGE, 2011) 78 (stating that the Crime and Disorder Act 1984 'ensured that the "principal aim" of the youth justice system would be to prevent offending by children and young persons'); R. Arthur, Young Offenders and the Law: How the Law Responds to Youth Offending (London: Routledge, 2010) 24-25 (discussing the youth protection system under the Crime and Disorder Act 1998).

122 See Crime and Disorder Act (n 54) s.39 (1)-(2), s.39 (7) and s.40(3); Arthur (n 121).

123 Kulach, Whiskin and Marks (n 117) 30. 
social programmes to address the socio-economic causes of crimes and PSP teams raise awareness amongst students of issues such as alcohol, drug abuse, discrimination and equality. ${ }^{124}$ The PSP provide training to the officers on such topics and collaborate with public and private actors in the development of those training sessions. ${ }^{25}$ The Romanian police also have powers to collaborate with educational institutions and NGOs to train and educate the public about the measures for countering juvenile delinquency. ${ }^{126}$ In Germany, the federal Commission on Police-Based Crime Prevention acts as a research centre to produce grass-root initiatives for crime prevention. ${ }^{127}$ Further, several states have developed neighbourhood watch groups to patrol schools and public parks. ${ }^{128}$ State laws regulate the work of these volunteer groups and give them some powers, including the power to ask a suspicious individual to leave the area. ${ }^{29}$ Also, the law in both Italy and France provides bases for volunteers' involvement in crime prevention activities. ${ }^{130}$

In all the selected jurisdictions, the police can exercise several traditional powers necessary for crime prevention, such as the power to stop and search or the power to detain. ${ }^{131}$

124 Ibid., 30-31; State Report (n 95) 26-27.

125 Ibid., 26-27.

126 Law 218/2002 on the Organisation and Functioning of Romanian Police (n 70) Art. 26. See also L. Capobianco. 2007. 'Key Developments, Issues, and Practices: The Role of the Police in Crime Prevention'. International Centre for the Prevention of Crime. November 2007. Retrieved 6 March 2017 www.crime-prevention-intl.org/fileadmin/user_upload/Publica tions/Key_Developments_Issues_and_Practices._The_Role_of_the_Police_in_Crime_ Prevention_ANG.pdf at 12 (arguing that educating the public about avoiding victimisation is a crime prevention measure).

127 Mohanty and Mohanty (n 106) 87-89; A.A. Jones and R. Wisema. 20o6. 'Community policing in Europe: Structure and best practices: Sweden, France and Germany'. Los Angeles Community Policing. 8 September 2006. Retrieved 6 March 2017 www.lacp .org/Articles\%20-\%2oExpert\%20-\%2oOur\%2oOpinion/o6o9o8-CommunityPolicingIn Europe-AJ.htm.

128 Mohanty and Mohanty (n 106).

129 See e.g. Section 5 Polizeigesetz des Freistaates Sachsen v. 13.08.1999, SächsGVBl. 466.

130 Ord. ${ }^{\circ}{ }_{12-351}$ du 12 mars 2012, art.L433-1; Italy: Legge 15 Luglio 2009, n. 94, in G.U. 24 Luglio 2009, Art. 3, paras. 40-44; Decreti Ministeriali 8 Agosto 2009, in G.U. 8 Agosto 2009, n. 183 , Art. 1.

131 See e.g. Art. 38-45 Gesetz über den Bundesgrenzschutz (n 112); Police and Criminal Evidence Act 1984 (n 109), Parts I-IV. See S.P. Lab, Crime Prevention: Approaches, Practices and Evaluations ( $7^{\text {th }}$ edn, NJ: Matthew Bender and Company, 2010) 211. 


\section{d Policing as a Service}

The police and other public institutions must deliver high quality services in order to maintain their legitimacy. ${ }^{132}$ 'Policing as a service' is also a characteristic of community policing that requires the police to take measures to improve the public's quality of life, in addition to the traditional role of crime control. ${ }^{133}$ A clear reflection of this duty is the 'Best Value' regime in England, under which the police and several other local authorities must 'secure continuous improvement in the way in which [their] functions are exercised, having regard to a combination of economy, efficiency and effectiveness. ${ }^{\prime 34}$ In other words, the police are providers of responsive and high quality services tailored to meet society's needs. ${ }^{135}$ They are accountable to the public they serve and thus must consult with them on particular issues such as the future of any of the services in the policing area, the assets allocated to the services and the services' impact on the community. ${ }^{136}$ Besides achieving 'Best Value' in their services, the English police have a duty to: (1) endeavour to deliver services tailored to improve the economic, social and environmental well-being

132 Ballantyne and Frase (n 5) 173; E. Mclaughlin, 'The democratic deficit: European Union and the accountability of the British police', British Journal of Criminology 32(4) (1992) 473-487. See also P. Butler, 'The system is working the way it is supposed to: The limits of criminal justice reform', The Georgetown Law Journal 104 (2016) 1419-1478 (noting that law enforcement is a public good).

133 H. Goldstein, 'Toward community-oriented policing: Potential, basic requirements, and threshold questions', Crime \& Delinquency 33(1) (1987) 6-30.

134 Local Government Act 1999, c.27, s.1(1)(a) and s.3(1). For a fuller discussion of the Best Value policy see P. Badcoe, 'Best value - An overview of the United Kingdom Government's policy for the provision and procurement of local authority services', Public Procurement Law Review 2 (2001) 63-81; D. Martin, 'The politics of policing: managerialism, modernization and performance', in: R. Matthews and J. Young (eds), The New Politics of Crime and Punishment (London: Routledge, 2011) 154-177.

135 Cabinet Office, Modernising government (London: The Stationery Office, 1999) 41; Leishman, Loveday and Frank (n 66) 3 (noting that the Best Value duty views the police as a service provider); Newburn (n 67) 118 (arguing that the Best Value regime negates the 'policy solution' to policing and encourages competition.).

136 The Local Government Act 1999 (n 134) s.3(2). See also I. Lelandais and J. Bodson. 2007. 'Measuring Police Performance: International Experiences'. International Centre for the Prevention of Crime. October 2007. Retrieved 6 March 2017 www.crime-prevention-intl .org/fileadmin/user_upload/Publications/Perf_Police_English_FINAL.pdf at 30; Department for Communities and Local government, Revised Best Value Statutory Guidance (London: Department for Communities and Local Government, 2015); Leishman, Loveday and Savage (n 66) 3 . 
in the communities they serve and seek to achieve a social value in their public service contracts ${ }^{137}$; (2) co-operate with local authorities to improve the wellbeing of children ${ }^{138}$; and (3) design and exercise their functions in a manner that reduces socio-economic inequalities and eliminates direct and indirect discrimination. ${ }^{139}$

The role of the police as a service provider is limited and less developed in the legislative and regulatory frameworks of the police in Germany, France, Italy, Romania and Portugal. Specifically, crime prevention bodies and partnerships usually provide society welfare services in the course of their efforts to prevent crimes in Germany. ${ }^{140}$ The police's involvement in improving the people's quality of life in France, Italy and Portugal mainly takes the form of victim and vulnerable group support programs. ${ }^{141}$ And, although the Romanian law requires the police to act 'in the interest and support of the person, the community and public institutions', ${ }^{142}$ 'display solicitude and respect for any person', ${ }^{143}$ and 'continuously improve their professional and general training level, ${ }^{144}$ the nature of these duties reflects the focus on the demilitarisation of the police more than on the improvement of the people's quality of life. ${ }^{145}$

137 Public Services (Social Value) Act 2012, c.3, preamble.

138 Children Act 2004, c.31, s.10 (1). See also HM Government, Statutory Guidance on Making Arrangements to Safeguard and Promote the Welfare of Children under Section 11 of the Children Act 2004 (London: Department for Education and Skills, 2007).

139 Equality Act 2010, c.15, s.1 (1). s.4, 13, 19, 26 and 27.

140 Feltes (n 77) 223.

141 See e.g. Ord. ${ }^{\circ}$ 12-351 du 12 mars 2012, art. L111-1; Law No. 112/2009, 16 September 2009; Ordinance 220-A/2010; Resolution of the Council of Ministers 102/2013 (n 118). See also State Report (n 95) 26-27 (noting that the PSP has offices designated for supporting the victims of domestic violence); Fernandes (n 91) (noting that the PSP forms victim support teams); CEDAW (n 94) (noting that the National Republican Guard (GNR) has special offices in which female officers provide help women victims of domestic violence); Capobianco (n 126) (arguing that providing support and advice to victims of crimes establishes confidence in the police and encourages crime reporting).

142 Law $360 / 2002$ on the Status of the Police Servants published in the Official Gazette no. 440/24.06.2002, Art. 3 .

143 Ibid., Art. 41(b).

144 Ibid., Art. 41(c).

145 See ibid., Art. 1(1): ('The police staff consists of civil servants with special status, armed, who usually wear a uniform and exert responsibilities established by law for the Romanian Police, as a specialised state institution'); Abraham (n 73) (arguing that the Romanian police are a service provider). Law No. 155/2010 on Local Police ( $\mathrm{n}_{72}$ ) requires the local police to provide social assistance to some groups, such as vulnerable homeless and parentless children. However, its impact on encouraging the local police to improve their services 
In 1829, Sir Robert Peel wrote: ' $[\mathrm{t}]$ he police are the public and the public are the police.'146 Today, community policing is a popular model of policing and an active topic of research. Community policing focuses on establishing a multipurpose partnership between the public and police. It adopts the philosophy that 'prevention is better than cure'. Additionally, it emphasises the role of the police as providers of high quality services that contribute to people's quality of life.

Community policing has legal bases in both EU law and the laws of the selected jurisdictions. It facilitates the function of the police to enforce the law in a manner consistent with the rule of law, which is a founding value of the $\mathrm{EU}$. Further, the European Parliament and Council can take steps that promote collaboration between the Member States in the field of crime prevention. In this respect community policing can be an important field of co-operation, given its popularity in the Eu Member States. It can also be one of the policing programmes for combatting cross-border serious crimes, on which the European Parliament and Council may adopt directives that define crimes and sanctions.

Community policing has legal bases in both the jurisdictions where the police enjoy a high level of public trust and the jurisdictions where public trust in the police is low. However, the maturity level of the jurisdiction's community policing legal framework is an important, though not determinative, factor in building this trust. In the selected jurisdictions, community policing's legal bases exist in a complex matrix of laws, regulations and policies, which are not always explicit in articulating its elements. Albeit not necessarily under the banner of community policing, the law in the selected jurisdictions requires, or supports, at least one of the main elements of this policing model. First of all, the English and Romanian legal systems establish a clear and explicit duty that requires the police to involve the public in setting policing priorities and strategies. In contrast, involving the public in this task is generally implied or optional in the laws of the other selected jurisdictions. It is therefore recommended that these jurisdictions follow the English model by establishing a clear statutory duty that requires the police to engage the public in establishing policing priorities and strategies.

Second, in England and Romania the police have a duty to take measures to secure the public's co-operation in crime prevention and detection, whereas

is uncertain. See I. Bilouseac, 'Decentralized public service of the local police', European Journal of Law and Public Administration 3(1) (2016) 13-19.

146 Peel (n 48). 
seeking this support falls within the discretionary powers of the Ministry of Interior and/or the police organisations in the other selected jurisdictions.

Third, England, Germany and Romania have in place a legal and institutional framework that facilitates studying the root causes of crimes and how to address them, especially amongst youth. The preventive policing philosophy is also visible in the Portuguese fifth National Plan against Domestic Violence and in the programmes for neighbourhood watch groups in Italy and France. These three jurisdictions, however, should adopt further legal and institutional measures that increase the enforcement of preventive policing, especially to combat offending by children and young persons, such as the establishment of national bodies that design and supervise the implementation of comprehensive crime prevention programmes.

Finally, the law in England establishes the police as providers of responsive and high quality services tailored to meet society's needs. Conversely, beyond crime control, the police's role in improving the people's quality of life is narrowly constructed in the other selected jurisdictions to focus on helping vulnerable groups and victims of crimes. To remedy this situation, these jurisdictions should establish a duty that requires the police to tailor their services, to the extent possible, to improve the quality of life in the communities they serve and to collaborate with other actors in the community for this purpose.

\section{Acknowledgements}

The research for this article received funding from HORIZON 2020 Programme: Secure societies - Protecting freedom and security of Europe and its citizens. G. A. Number: 653811 . 